\title{
On Wondersella athersuchi, a new stratigraphically significant hedbergellid foraminiferan from the Cretaceous Shuaiba Formation of the Middle East
}

\author{
F. T. BANNER ${ }^{1} \&$ A. R. E. STRANK ${ }^{2}$ \\ ${ }^{1}$ Department of Geology, University College, London WC1E 6BT \\ ${ }^{2}$ Exploration \& Production Research Division, British Petroleum Research Centre, Sunbury-on-Thames, Middlesex TW16 7 LN
}

\begin{abstract}
Wondersella athersuchi, gen. et sp. nov., is a uniquely streptospiral hedbergellid apparently confined to the latest Aptian in pelagic micritic limestones of the Middle East. This taxon probably characterised highly stratified, oceanic-marginal environments of central, palaeoequatorial Tethys.
\end{abstract}

\section{INTRODUCTION}

Recent micropalaeontological studies of the Lower Cretaceous Thamama Group sediments from the Middle East have revealed several new taxa. This paper deals with one new planktonic genus and species which is stratigraphically restricted to the highest part of the Shuaiba Formation equivalent, and has, to date, been found in cores from the ADMA-OPCO Well Zakum-1 and the ADMA Well Umm Shaif-3, offshore Abu Dhabi (Fig. 1).

The nomenclature of the stratigraphic units adopted for this publication (Fig. 2) are those of Hassan et al. (1975). Supporting data have been taken from extensive proprietary stratigraphic and biostratigraphic studies of the offshore Abu Dhabi area, and datings have been subjected to minor revision as shown on Fig. 2 .

\section{STRATIGRAPHY AND MICROPALAEONTOLOGY}

The type section of the Shuaiba Formation is the subsurface section of BPC Well Zubair No. 3, South Iraq (Dunnington et al., 1959); the interval 6856 - 7084 $\mathrm{ft}$. in the Well Zakum-1 is the reference equivalent section in offshore Abu Dhabi. The upper contact with the Nahr Umr shales (Fig. 2) is sharply defined and is probably unconformable throughout the Umm ShaifZakum offshore area. The lower limit of the Shuaiba Formation is the contact between basal porous limestones with the argillaceous limestones of the underlying Kharaib Formation. The Shuaiba, which is equivalent to the upper and middle parts of the Thamama Zone I succession of ADMA, can be divided into two members. The upper member comprises biolclastic wackestones together with pyritic shales, micrites and bituminous mudstones, and has a high gamma ray response. The upper member equates with the Bab Member of Hassan et al. (1975). The lower member comprises predominantly chalky foraminiferal grainstones with a clean gamma ray signature. The Shuaiba thins from over $300 \mathrm{ft}$. to less than $150 \mathrm{ft}$. in the central offshore Abu Dhabi area by loss of the highest beds beneath the basal Nahr Umr unconformity. In Zakum-1 the thickness is $238 \mathrm{ft}$., and most or all of the highest beds appear to be present.

On the basis of the contained foraminifera, regional correlations with ammonite dated sequences and its relative stratigraphic position, the Shuaiba Formation in the offshore Abu Dhabi area may be dated as Aptian to earliest Albian in age, as suggested by Hassan et al. (1975). In Zakum-1, the highest Shuaiba Formation contains Choffatella decipiens (Valanginian-Cenomanian), Buccicrenata hedbergi (Barremian-Albian), Hemicyclammina sigali (Albian-Cenomanian) and Orbitolina discoidea sensu Henson (BarremianCenomanian) confirming an Albian age for this interval. Immediately below the lowest $H$. sigali, $W$. athersuchi occurs, together with Marssonella $g r$. praeoxycona, Hedbergella aff. excelsa, Placopsilina sp., Epistomina (Brotzenia), rotalids, lituolids and small loftusiids which are referred to the latest Aptian. These taxa, with associated metazoan and algal debris, indicate a stable carbonate shelf environment, varying in palaeodepth from C. $50 \mathrm{~m}$ to more than $90 \mathrm{~m}$ b.s.l.

The new taxon Wondersella arhersuchi is confined to a relatively deep water carbonate micrite facies (Pl. 4) near the base of the Bab Member (Fig. 2). Its type horizon of occurrence is a bed about $2 \mathrm{ft}$ thick, cored at 7036 - $7037 \mathrm{ft}$ BRT in Zakum-1 (Fig. 1), about $9 \mathrm{ft}$ above the top of Thamama Zone IA of Hassan et al. (1975, Fig. 3); it also occurs $60 \mathrm{~km}$ away in the nearby Umm Shaif field (US-3, core at $5857 \mathrm{ft}$ BRT), $5 \mathrm{ft}$ above the top of Thamama Zone IA, a precisely equivalent horizon. 




Fig. 1. Location of the Umm Shaif (US-3) and Zakum (ZK-1) fields, offshore Abu Dhabi.

\section{Explanation of Plate 1}

Wondersella athersuchi gen. et sp. nov.

Figs. 1-9. Axial and oblique-axial sections. Shuaiba Formation, Zakum-1 Well, core at 7037ft BRT, Abu Dhabi. All figures are $\times 200$.

Fig. 1. Immature paratype which is still wholly trochospiral and has not yet acquired streptospirality: such forms are rare in the slides from the type core.

Figs. 2-9. Specimens showing the development of angularity and streptospirality, with umbilical closure well displayed in fig. 6. Fig. 9, holotype, P52040.

Fig. 8. The apparent terminal biseriality is attributed to the section cutting the area of embrace of two successive, flaring chambers. 


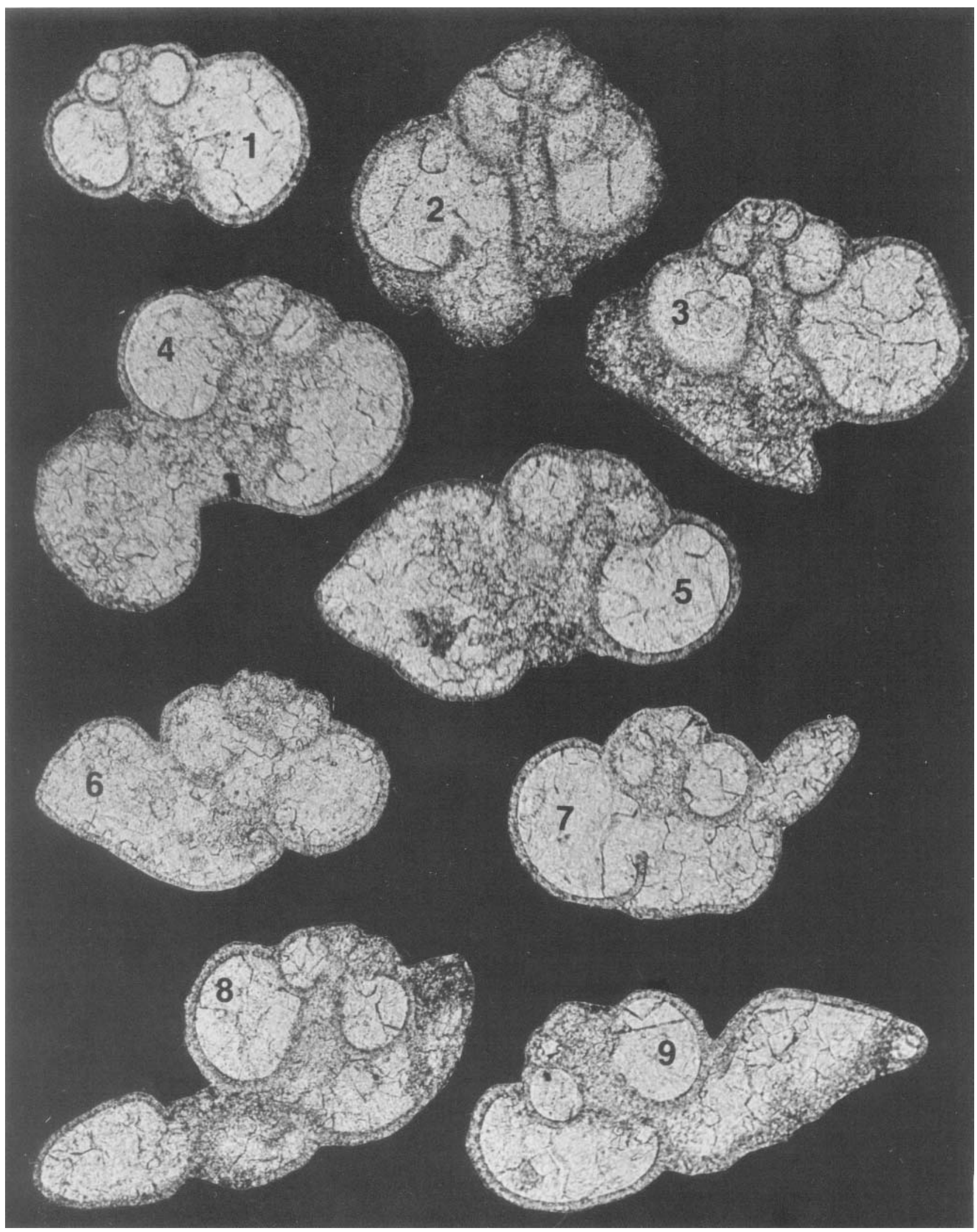




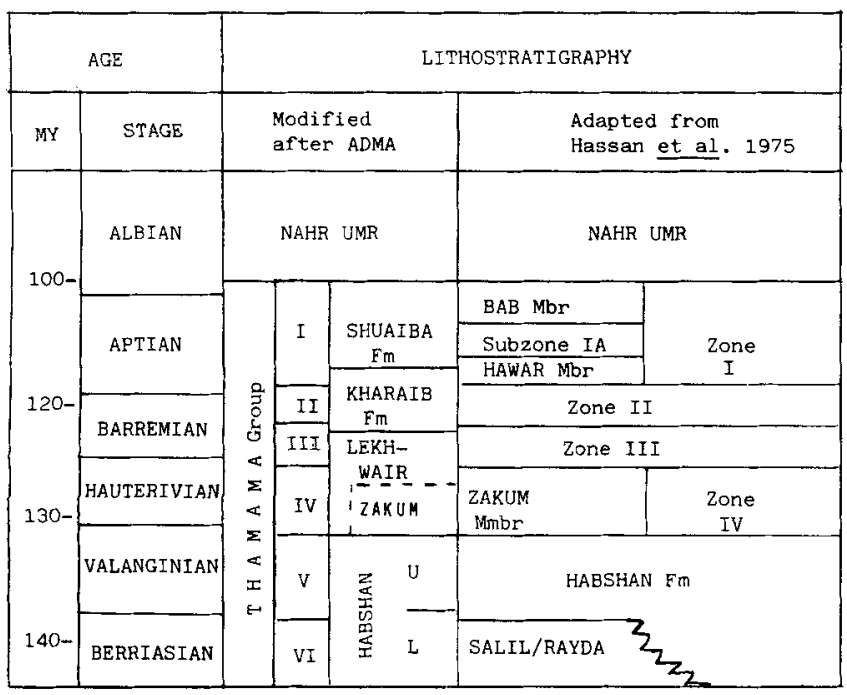

Fig. 2. Early Cretaceous lithostratigraphy, offshore Abu Dhabi.

\section{SYSTEMATIC PALAEONTOLOGY}

Family Rotaliporidae Sigal, 1958

Subfamily Hedbergellinae Loeblich \& Tappan, 1961 Genus Wondersella gen. nov. (Fig. 3)

Type Species. Wondersella athersuchi gen. et sp. nov. Monotypic.

Derivation of name. After Dr. A. A. H. Wonders in recognition of his research into Tethyan Cretaceous planktonic foraminifera.

Type Locality. Shuaiba Formation, core at $7036-37 \mathrm{ft}$, Well Zakum-1, offshore Abu Dhabi.

Diagnosis. A hedbergellid in which the early trochospiral test is followed by a streptospire. The chambers increasingly embrace the umbilical side, even to enclose the umbilicus, and grow irregularly, typically with marked radial elongation and peripheral angularity. There are no supplementary apertures developed on the spiral side.

Remarks. The ventrally-directed streptospirality of the last whorl distinguishes the genus from all others of the Rotaliporidae. It is the only Cretaceous genus of the Globigerinina in which such coiling occurs. It differs from Pulleniatina (Pulleniatininae, Neogene-Recent) in being initially a Hedbergella in its wall, umbilical and (we believe) apertural characteristics. The onset of ventrally-directed streptospirality in Pulleniatina is progressive (Banner \& Blow, 1967) whereas in Wondersella it is abrupt, terminating a well developed regular trochospire with its true, deep umbilicus.

This taxon is distinguished from Hedbergella at generic level because, if it were not, the amended diagnosis for Hedbergella would become too broad to retain that genus usefully.

The chambers of the first streptospiral whorl of Wonderella athersuchi become subangular at their peripheries (Fig. 3, Pls. 1-3), and the posterior part of the periphery becomes elongate as in Hedbergella (Asterohedbergella) asterospinosa Hamaoui. In fact, equatorial sections can look very similar indeed (Pl. 2, figs. 2, 7; compare Hamaoui, 1965, pl. 1, figs. 16, 17). However, H. (A.) asterospinosa is not known to develop ventrally-directed streptospirality, and, as it is not known below the Cenomanian (Hamaoui, 1965; Saint-Marc, 1970, p. 92), it cannot be ancestral to Wondersella.

\section{Wondersella athersuchi sp. nov.}

(Pl. 1-4; Fig. 3)

Holotype. Pl. 1, fig. 9, Shuaiba Formation, Well Zakum-1, core at $7037 \mathrm{ft}$, offshore Abu Dhabi.

Holotype and associated paratypes (Pl. 1) in the British Museum (Natural History), slide reg. no. P52040. Other paratypes P52041 - P52043; all other specimens in the collections of the British Petroleum Co. Ltd., Research Centre, Sunbury-on-Thames, Middlesex TW16 7LN.

Derivation of name. After Dr. J. Athersuch in recognition of his (proprietary) biostratigraphic research on the Middle East.

Description. The first two to three whorls consist of regularly enlarging chambers in a uniform trochospire $0.25-0.3 \mathrm{~mm}$ in diameter. The spiral side of the trochospire is wholly evolute and convex, with an apical angle averaging about $120^{\circ}$ (Pl. 1, fig. 3) but ranging from about $110^{\circ}$ (Pl. 1, fig. 2) in very high-spired forms to about $140^{\circ}$ (Pl. 1, figs. 1, 6) in relatively low spired specimens. The trochospire has five chambers in each whorl (Pl. 2, figs. 2, 3, 5; PI. 3, fig. 8) sometimes reducing to four as the chambers become longer and more depressed (Pl. 2, figs. 7, 9). The chambers are initially globular (Pl. 1, figs. 1-9; Pl. 2, figs. 1-3, 5; Pl. 3, figs. 9-13) becoming laterally compressed and ovoid in axial section (higher than broad) (PI. 1, figs. 1-9; Pl. 3,

\section{Explanation of Plate 2}

Wondersella athersuchi gen. et sp. nov.

Figs. 1-10. Equatorial and oblique-equatorial sections. Shuaiba Formation, Zakum-1 Well, 7037ft BRT, Abu Dhabi. All figures are $\times 200$. 


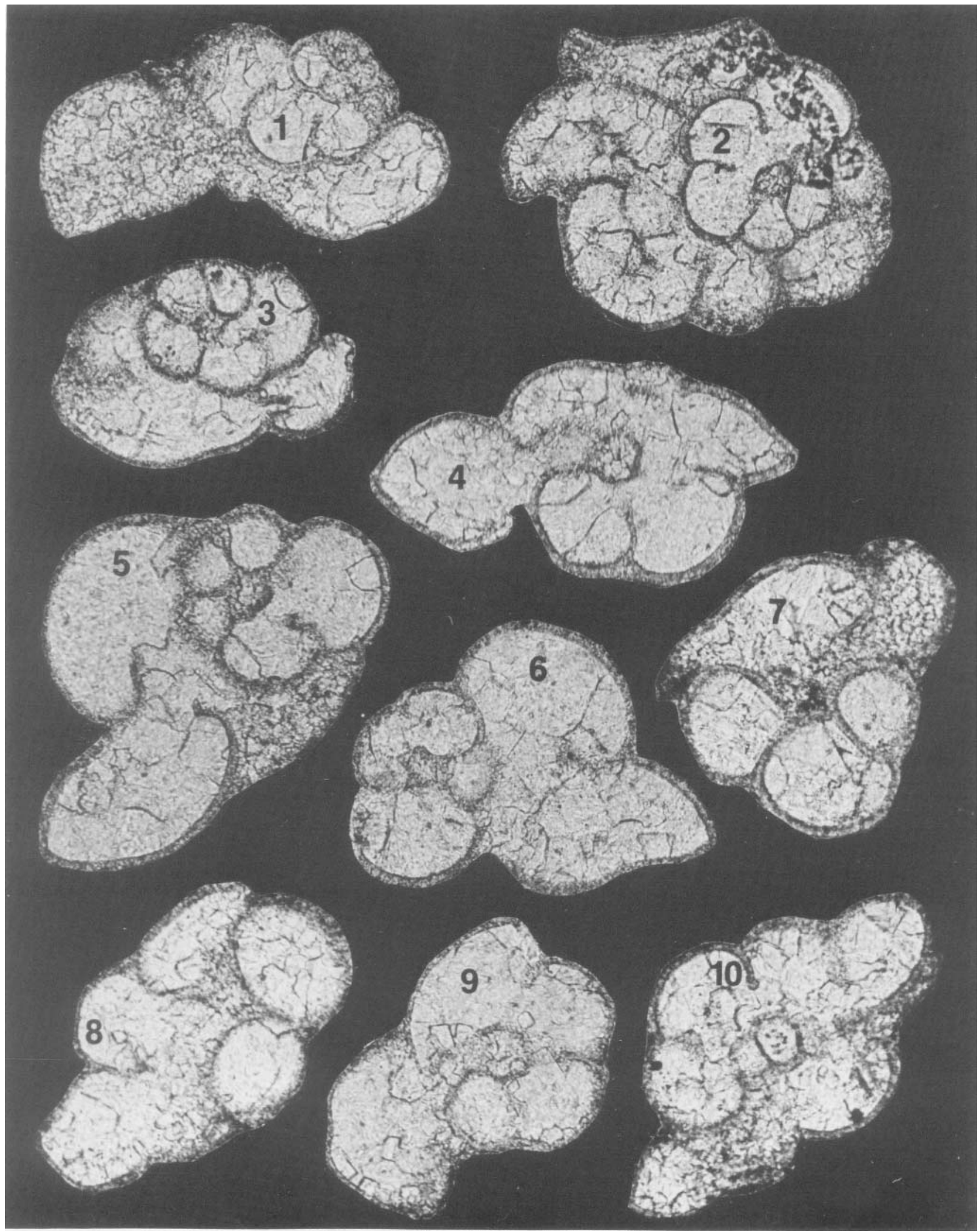


figs. $1-4,6,7,10)$ and more reniform in the equatorial plane (Pl. 2, figs. 2, 3, 8, 10). The trochospire has a deep, parallel-sided, open umbilicus, with diameter about $30-40 \%$ that of the umbilical depression and 20 $-25 \%$ that of the trochospiral test. The aperture is umbilical-extraumbilical (Pl. 1, fig. 2; Pl. 2, figs. 2, 6, 10; P1. 3, figs. 5-8) and may possess a sharply reflexed porticus (Pl. 1, fig. 2; Pl. 3, fig. 3) especially developed in its posterior (more umbilical) part. The spiral and intercameral sutures are distinctly depressed but are not incised or limbate. The test surface is smooth and finely perforate (diameter about $5 \mu \mathrm{m}$; i.e. of hedbergellid rather than globuligerinid dimensions - see Banner, 1982, pp. 199-200).

The onset of streptospirality (during or at the end of the third whorl) is marked by increased compression of the chambers, which encroach upon and partly or wholly cover the umbilicus (P1. 1, figs. 8, 9). The chambers also rapidly become compressed dorsoventrally and acquire peripheral angularity ( $\mathrm{Pl}$. 1, figs. $5,6,8,9$; PI. 3, figs. $1,4,7$ ) without the development of any keel or muricocarina. The posterior parts of the chambers broaden and often become elongate into backwardly-pointing ogival forms (Pl. 2, figs. 2, 4, 7, $8)$. This radial elongation rapidly accelerates as the chambers become more umbilically placed (P1. 1, figs. $6,8,9$; Pl. 2, figs. 1, 4, 5-10) and the chambers become pointed-spatulate, peripherally acutely angular and compressed, but still with convex surfaces both ventrally and dorsally. Each embraces about one-half of the preceding, so that axial sections may cut two or even three successive chambers, giving a false impression of rectilinearity and even biseriality (Pl. 1, fig. 8; Pl. 3, figs. 11-13). The shape of the streptospiral chambers is undoubtedly variable between specimens, but their apparent breadth in axial thin section is affected by their asymmetry in equatorial plan (Pl. 2, figs. 6, 8; compare Pl. 1, figs. 3, 6 and Pl. 3, figs. 4, 7). The encroachment upon, and then the closure, of the umbilicus by streptospirality, forces the aperture of each later streptospiral chamber to become extraumbilical. It is not known if this taxon retains a porticus, but there are indications (Pl. 2, fig. 5) that it does. The flaring, streptospiral chambers may occupy half the total test diameter (which reaches $0.4-0.5 \mathrm{~mm}$ ); the test remains smooth and uniformly perforate, and the test walls do not alter their thickness, structure and surface texture with the change of coiling mode and chamber shape.

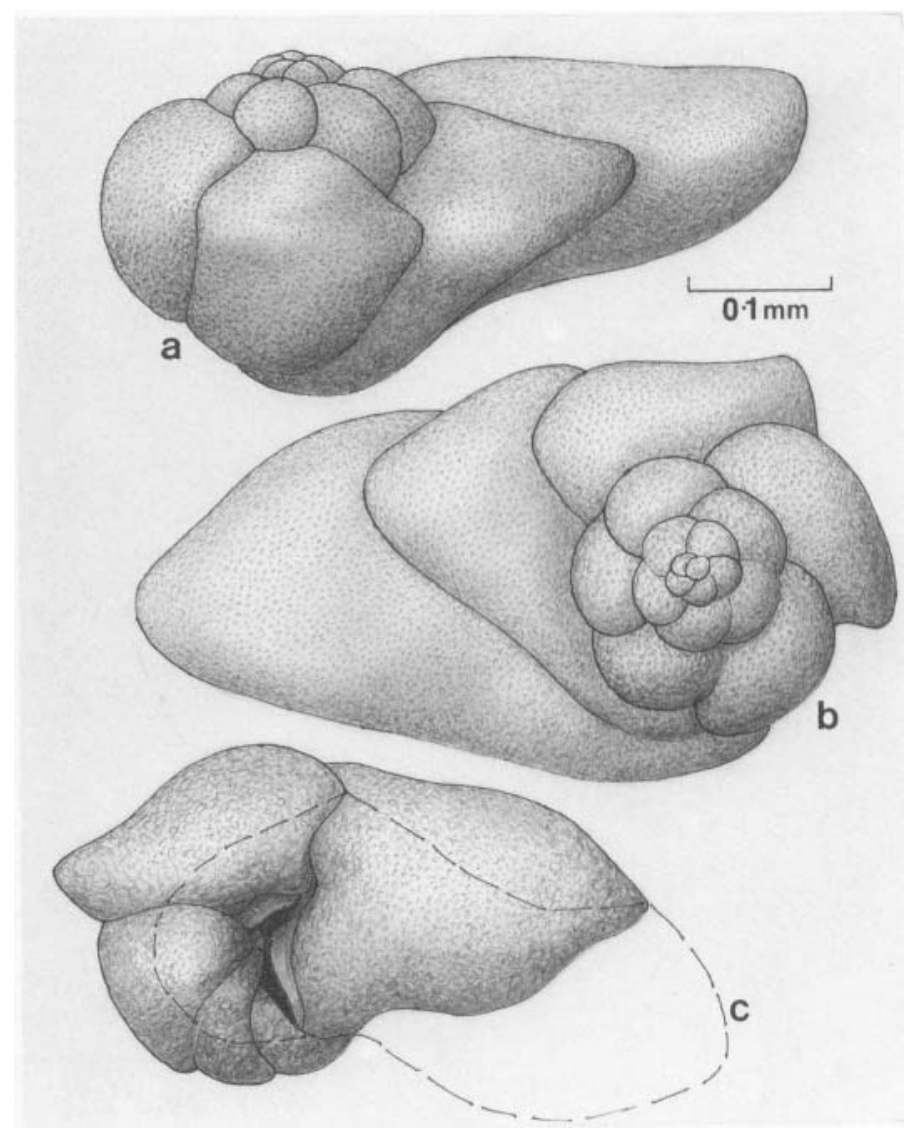

Fig. 3. Reconstructions (from the thin sections of Pls. 1-3 and others) of the external appearance of Wondersella athersuchi: 3a, lateral; 3b, "dorsal" (spiral) and 3c, "ventral" (umbilical views) of a specimen developed in the manner of the holotype (P1. 1, fig. 9). Fig. 3a shows the umbilicus incompletely closed, but a dashed line indicates how the addition of one further chamber closes the umbilicus.

The external appearance of typical $W$. athersuchi is reconstructed in Fig. 3; in other, wholly conspecific forms, the final chambers may be more ventrally directed (extremes shown on Pl. 3, figs. 5, 5a, 6).

Remarks. The extraordinary shape of the later chambers in $W$. athersuchi cannot be due to post-depositional compression and distortion. The sediments in which the assemblages occur, although microbedded, contain abundant tests in all orientations (Pl. 4) and yet it is

\section{Explanation of Plate 3 \\ Wondersella athersuchi gen. et $\mathrm{sp}$. nov.}

Figs. 1-14. Various axial and oblique orientations; Shuaiba Formation, Zakum-1 Well, Abu Dhabi; fig. 12, 7037ft BRT; figs. 13-14, 7036ft BRT. All figures are $\times 200$. 


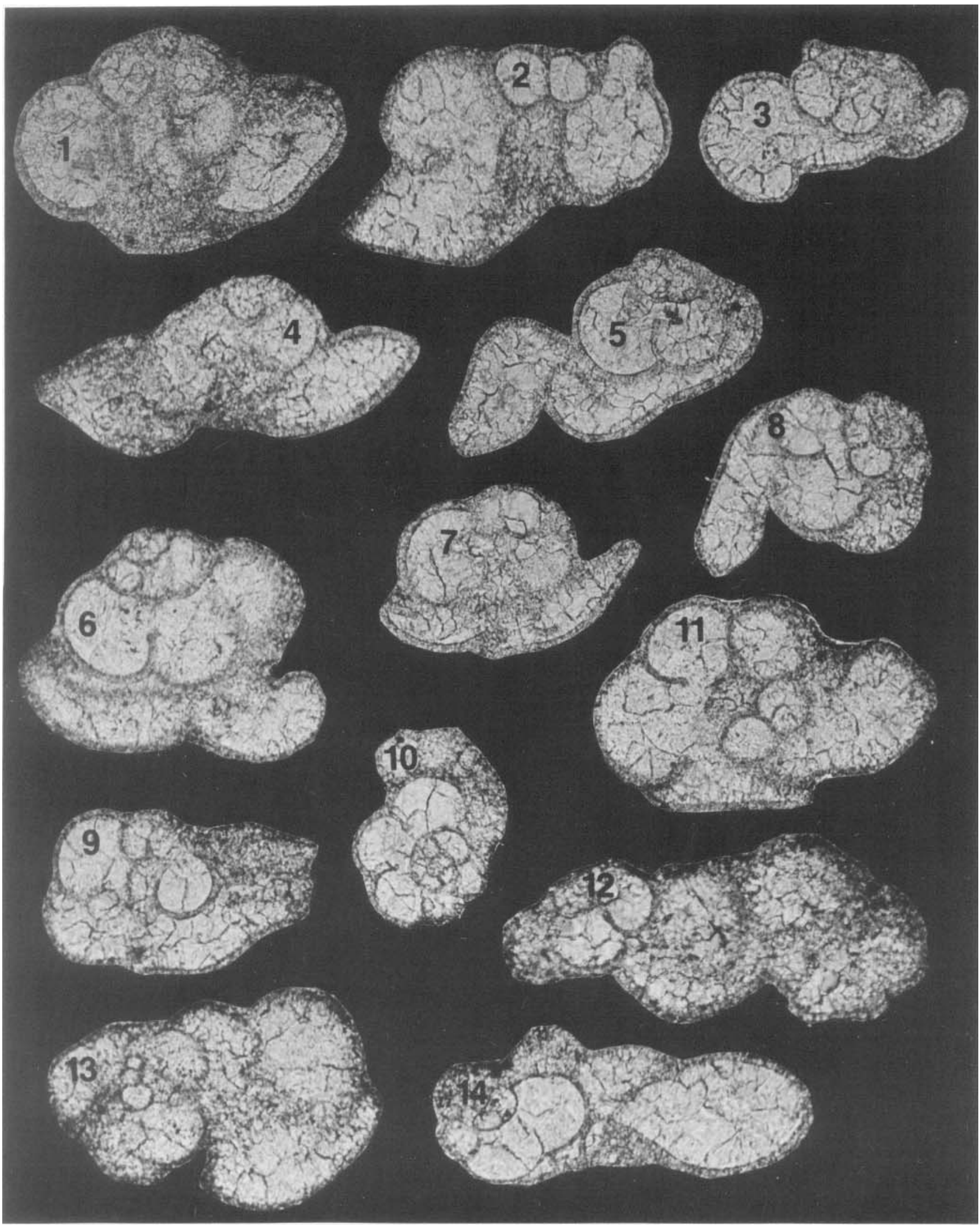


only the chambers of the last one or two whorls which are of exceptional shape (the early growth stages of all are regular, uniform trochospirals). Also, the other microfossils (e.g. Marssonella, Pl. 4, fig. 1; fish vertebra, Pl. 4, fig. 3) show no significant distortion. Finally, it would be impossible for post-mortem deformation to create the elongate, falciform shapes of the later chambers in equatorial section (Pl. 2, figs. 2, 4,7 ) or the umbitical closures in axial section (Pl. 1, figs. 7-9), especially without deformation of the ontogenetically earlier chambers.

Discussion. The nearest morphological analogy to the irregularly placed, flaring, compressed chambers of the last whorl of Wondersella are the similarly flaring, compressed and sometimes abnormally placed final chamber (rarely, two chambers) of Globigerinoides quadrilobatus (d'Orbigny) forma sacculifer (Brady) (Early Miocene - Recent worldwide), G. quadrilobatus fistulosus (Schubert) and G. quadrilobatus hystricosus Belford (both Pliocene, Indo-Pacific); however, in none of these is streptospirality and umbilical closure attained, and the phylogenetic separation of these forms from Wondersella is likely to preclude even homology between the terminal structures. In any case, the significance of sac-like terminal chambers in $G$. quadrilobatus is itself unknown: attempts to correlate the distribution of $G$. quadrilobatus f. sacculifer in the Gulf of Elat with seawater temperature, density and nutrition have met with no success (Reiss \& Halicz, 1976) and no explanation could be offered for the frequency of individuals with sac-like chambers (Reiss, 1977).

The abundance of Wondersella within its stratigraphic interval (representing at least 30,000 years of geological time in the Zakum Section) suggests that it is not an abnormal phenotype of another (unknown) Hedbergella, but an opportunistic incursion of an ecologically (and, therefore, palaeobiogeographically) restricted species. The benthic foraminiferal fauna of the Wondersella horizon is poor both in numbers and diversity; the presence of pyrite, limonite and fish debris (Pl. 4, fig. 3) also suggests oxygen-deficient bottom waters, confirmed by lack of metazoan debris and bioturbation in the microbedded micrite (Pl. 4). It is probable that the waters were, during this phase of shelf deepening, strongly density-stratified, perhaps due to incursions of highly saline waters into this subtropical gulf and on its deepening carbonate shelf. It may be that Wondersella athersuchi was a species characterising warm, highly saline outer shelf waters of low turbidity in central, equatorial Tethys during Latest Aptian time.

\section{ACKNOWLEDGEMENTS}

The authors are grateful to ADMA-OPCO, Abu Dhabi, for the provision of the Zakum-1 cores and associated thin sections. We acknowledge the financial support and technical facilities supplied by the British Petroleum Co. p.l.c. and appreciate the permission to publish granted by the Abu Dhabi Marine Operating Company Ltd. (ADMA-OPCO) and BP Research Centre, Sunbury-on-Thames, Middlesex. F.T.B. also acknowledges the grant from N.E.R.C. supporting his research into Early Cretaceous planktonic foraminifera.

Manuscript received March 1986

Revised manuscript accepted July 1986

\section{Explanation of Plate 4}

Figs. 1-6. Shuaiba Formation, Zakum-1 Well, Abu Dhabi; successive horizons upwards through cores covering the $7036-7037 \mathrm{ft}$ BRT interval. All figures are $\times 50$. 
Wondersella athersuchi, a new Middle East hedbergellid
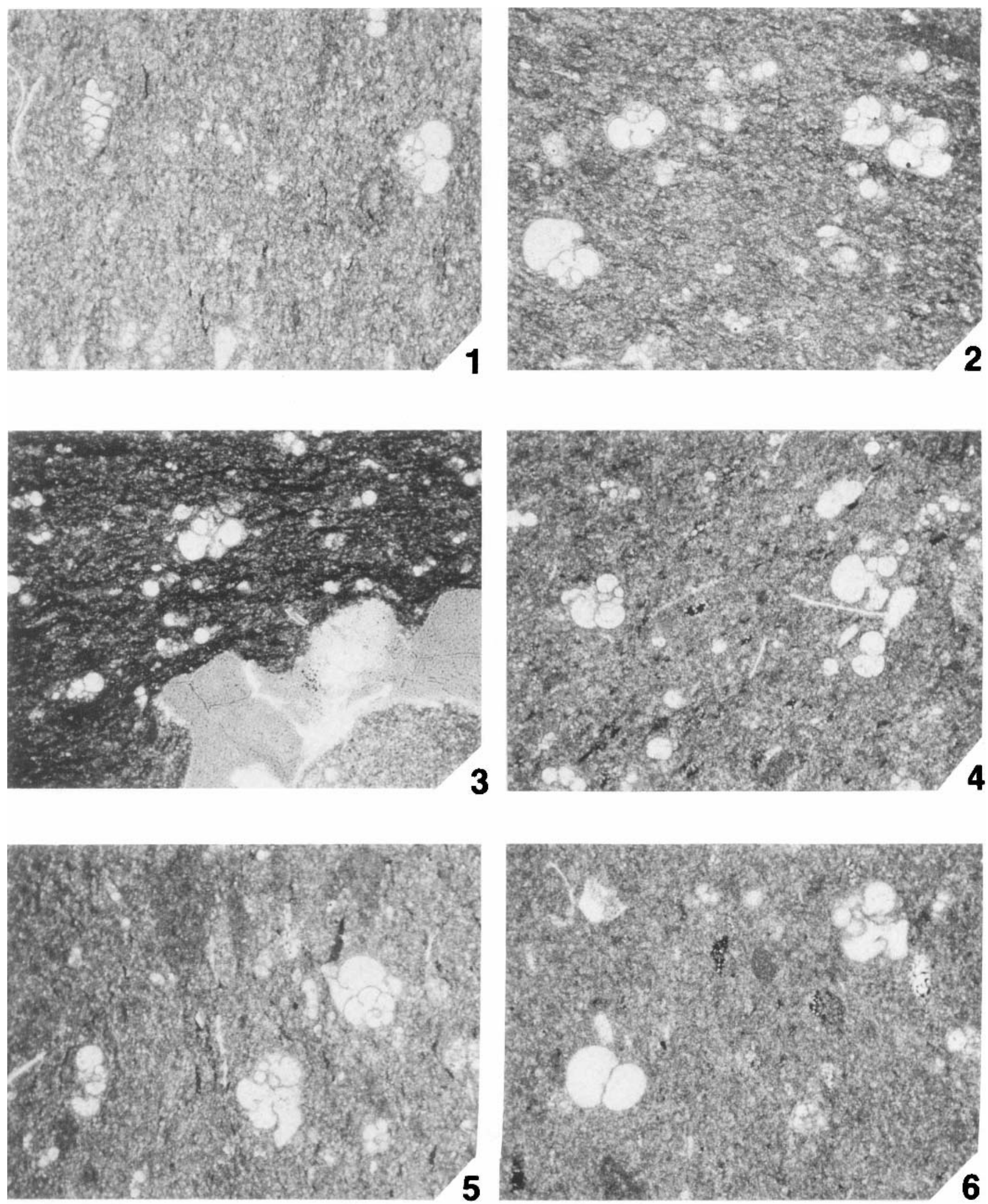


\section{REFERENCES}

Banner, F. T. 1982. A classification and introduction to the Globigerinacea. In Banner, F. T. \& Lord, A. R., Aspects of Micropalaeontology, 142-239, Allen \& Unwin, London.

Banner, F. T. \& Blow, W. 1967. The origin, evolution and taxonomy of the foraminiferal genus Pulleniatina Cushman, 1927. Micropaleontology, New York, 13, 133-162.

Caron, M. 1985. Cretaceous planktonic foraminifera. Chapter 4 In Bolli, H. M., Saunders, J. B. \& Perch-Nielsen, K., Plankton Stratigraphy, 17-86. Cambridge University Press.

Dunnington, H. V., Wetzel, R. \& Morton, D. M., 1959. Lexique Stratigraphique International, Asie, fasc. 10a, Iraq; Mesozoic and Palaeozoic. C.N.R.S., Paris.

Hamaoui, M. 1965 (1964). On a new subgenus of Hedbergella. Israel J. Earth Sci., 13, 133-142.

Hassan, T. H., Mudd, G. C. \& Twombley, B. N., 1975. The stratigraphy and sedimentation of the Thamama Group (Lower Cretaceous) of Abu Dhabi. 9th. Ann. Arab. Pet. Cong. Proc. 107, (B-3), 1-11.

Longoria, J. F. (1974). Stratigraphic, morphologic and taxonomic studies of Aptian planktonic foraminifera. Rev. Esp. Micropal., numero extraord., 1-107.

Reiss, Z. 1977. Foraminiferal research in the Gulf of Elat-Aqaba, Red Sea - a Review. Utrecht Micropaleontological Bulletins, 15, 7-25.

Reiss, Z. \& Halicz, E. 1976. Phenotypy in planktonic foraminiferida from the Gulf of Elat. Israel J. Earth Sci., 25, 27-39.

Saint-Marc, P. 1970. Sur quelques foraminiferes Cenomaniens et Turoniens du Liban. Revue Micropaléont., Paris. 